\title{
AREA-DIFFERENTIATED MODELING OF WATER BALANCE IN PINIOS RIVER BASIN, CENTRAL GREECE
}

\author{
PANAGOPOULOS A. ${ }^{1}$ \\ ARAMPATZIS G. ${ }^{1}$ \\ KUHR P ${ }^{1}$ \\ KUNKEL R. ${ }^{2}$ \\ TZIRITIS E. ${ }^{1, *}$ \\ WENDLAND F. ${ }^{2}$
}

\author{
${ }^{1}$ Hellenic Agricultural Organisation, Land Reclamation Institute \\ 57400, Sindos, Greece \\ ${ }^{2}$ Forschungzentrum Juelich $\mathrm{GmbH}$
} Agrosphere Institute (IBG-3), D-52425 Juelich, Germany

Received: 02/04/2014

Accepted: 22/01/2015

*to whom all correspondence should be addressed:

Available online: $27 / 02 / 2015$ e-mail: tziritis@gmail.com

\section{ABSTRACT}

GROWA is a modular grid based empirical hydrological model that is being used to address practical water resources management related issues. It has been successfully applied in typical hydrological and hydrogeological setups of northern European basins ranging typically between meso-scale river basins of about $1000 \mathrm{~km}^{2}$ to entire States or river catchments of $100,000 \mathrm{~km}^{2}$ or more. This paper examines the applicability of this model in a typical southern European environment where the typical water resources management pattern and also the controlling hydrodynamic evolution patterns differ considerably. As such, the River Pinios basin in central Greece, which has a spatial extent of some $11.000 \mathrm{~km}^{2}$, is studied. Model compilation was based on long-term average climatic and hydrological data for a reference period of 23 years (1980-2002) and validation performed against 12 river discharge gauging stations distributed in the study basin. Specific discrepancies that were denoted are attributed to the importance of secondary processes in the evolution of the studied system (e.g. overall water use, groundwater crossflows). It is concluded that prior to model recalibration efforts special attention should be given to the inclusion of such processes (water gains and losses) into the model runs. Total runoff and groundwater recharge should consequently be linked to the overall water use and secondary inputs before they are used for strategic water resources management. Overall, GROWA was successfully applied in this typical Mediterranean Basin, despite the totally different climatic, pedological, hydrological and hydrogeological conditions for which it was originally designed and tested.

Keywords: water balance, water resources management, GROWA model, Pinios Basin, Thessaly

\section{Introduction}

Application of suitable water resources management strategies and policies is a key priority for modern societies which are in need of integrated management plans, based on accurate and up-to date data sets, in order to provide holistic management strategies that focus on sustainable development. These plans shall incorporate a broad range of technical, legislative, and organizational components on a catchment scale level, which represent the natural entity of water resources management. It is fundamental to acquire reliable information about water availability, hence water resources management primarily aims at exploiting efficiently the available natural water flows, including surface and groundwater, so as to 
satisfy the arising competing needs. In than context, hydrological models are valuable tools in the design and assessment of alternative water resources management plans.

The development of hydrological models started in the 60's with the Stanford Watershed Model (Crawford and Linsley, 1966). Since then the number of models and model systems as well as the number of different model concepts has grown considerably, already in the mid-90s. All models have been developed for simulation of specific aspects of the hydrologic cycle and for a specific scale. Process-based hydrological models like PRMS, TOPMODEL, SHE or WaSiM-ETH for instance, have been developed to simulate the water flow and water balance in micro - to mesoscale watersheds. The problem of applying small-scale models to large catchment areas has lead to the development of models especially designed for macroscale applications. These models differ significantly from micro- and mesoscale models with respect to the representation of the relevant processes and their spatial and temporal resolution. But again, the specific objectives of the model development have to be taken into account.

The RHINEFLOW model for instance, calculates the water balance for the Rhine River basin using a more integrated approach on a monthly basis. The HBV-model is a more deterministic approach to forecast runoff for larger areas using a daily resolution. LISFLOOD is a GIS-based hydrological rainfall-runoff-routing model that can be applied for issues like flood forecasting and assessing the effects of river regulation measures and land-use changes in large and transnational catchments. On the global scale the WGHM model and the PCR-GLOBWB model have been developed to estimate global groundwater recharge as part of the global hydrological cycle.

Empirical models turned out to be sufficient for modelling mean long-term water balance in large catchment areas or regions (e.g. Jankiewics et al., 2005). These models allow a reasonable determination of long-term groundwater recharge rates as reference values for a sustainable groundwater management e.g. in the framework of the quantitative status assessment according to the EU-WFD (2000).

This study focuses on Pinios River Basin which is the largest fully developing in Greece and its significance is paramount in terms of local and national development. Pinios Basin is one of the key basins of the country in terms of agricultural production and as such sustains large part of the gross national economy, following a major investment made in the 1960's in the form of the "Project for the Development of Water Resources of Thessaly". Over the years, various studies have been elaborated dealing directly or indirectly with the water resources of River Pinios Basin. Among others, these studies aimed in water quality characterization and pollution assessment, water management policies and public participation, development of water balance based hydrological indices, water balance modeling for hyrdo-technical projects, support of seasonal soil compartment models and surface water quality and quantity assessments. Despite aforementioned studies, the lack of coordinated water resources management policies until recently, have led to the establishment of deficient water balance conditions and water quality deterioration (Panagopoulos et al., 2012; Alexandridis et al., 2014). In an attempt to restore documented quality and quantity issues, the Hellenic Min. Environment, Energy and Climate Change (2013), has approved an integrated management plan for the river basin in accordance to the specifications of Directive 2000/60/EC. Nevertheless, neither this nor aforementioned studies provided a detailed area differentiated model for the major runoff components (surface runoff, interflow and groundwater recharge), in order to acquire a supervisory view of total runoff in terms of water resources recharge which may be consequently linked with the overall water use and demand for strategic planning. This lack of information is attempted to be covered via the application of the water balance model GROWA (Kunkel and Wendland, 2002) which was initially applied successfully in the specific conditions of central Europe (Germany).

The hydrogeological set up of the entire basin is highly diversified compared to the typical setup of a central European river basin. On top, the typical water resources management pattern adopted in Thessaly, as well as data availability and infrastructure exhibit significant differences from those of the typical central European basins. Hence, the primary goal of this paper is the derivation of an accurate and up-to-date water balance model for River Pinios Basin, and to test and evaluate the potential success and 
transferability of GROWA model in totally different climatic, hydrological and hydrogeological conditions like those of Mediterranean regions.

\section{Study area}

River Pinios Basin is one of the largest, intensively cultivated and highly productive basins of the country and is located in central Greece with total surface area of approximately $11.000 \mathrm{~km}^{2}$ (Figure 1). It is characterized by highly diversified geological, hydrological and hydrogeological conditions and marked by the systematic exploitation of its water resources since early 1960's. River Pinios and its main tributaries - Enipeas, Titarisios, Litheos and Kalentzis - traverse the plain area.

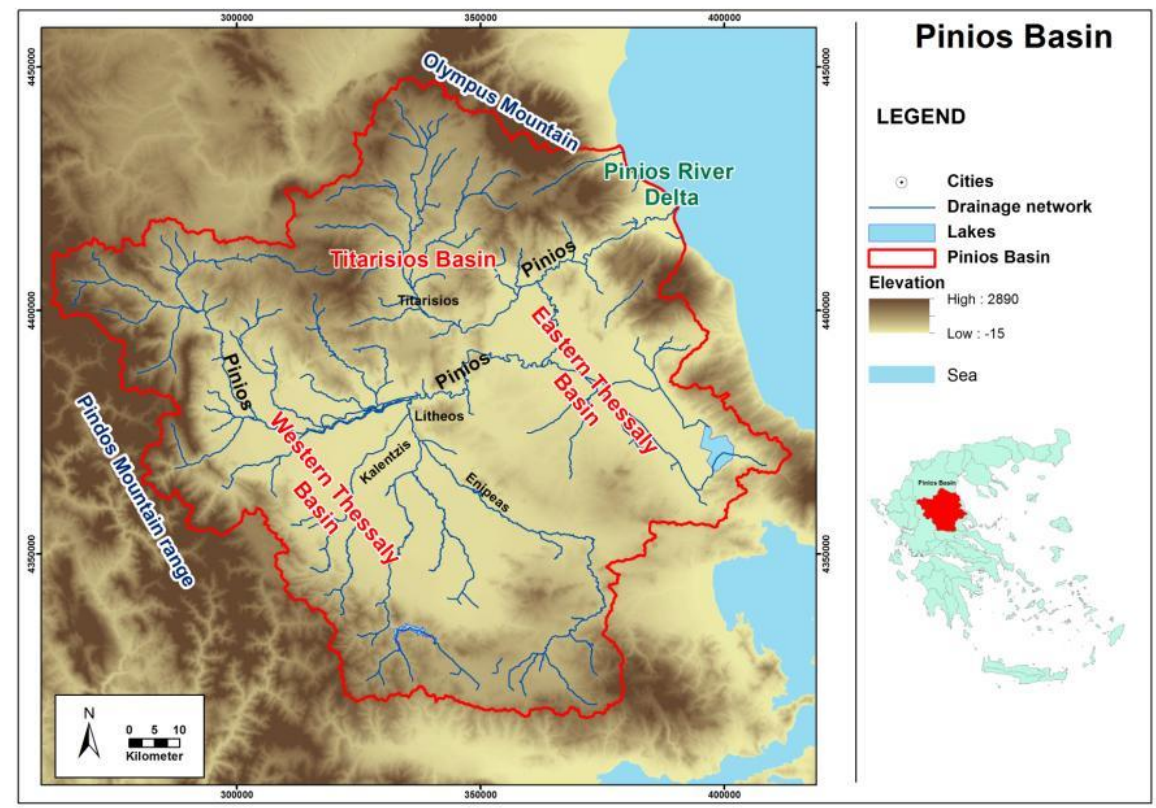

Figure 1. Outline of Pinios River Basin and main drainage network

The climate is typical Mediterranean (Alexandridis et al., 2014). Based on the analysis of available meteorological data (years 1980-2002), as these are discussed in chapter 3 of the paper, mean annual precipitation is $791 \mathrm{~mm}$ and mean annual temperature is $14.6^{\circ} \mathrm{C}$. Precipitation is distributed mostly during the cold season, without any significant precipitation during the hot summer at the plains of the basin.

The wider region is tectonically active and fault and fold tectonics control its geological evolution (Figure 2). A rugged topographic relief that reaches altitudes of over $2000 \mathrm{~m}$ bounds the basin, whereas the plains are characterized of quasi-flat topographic surfaces that extend from almost $200 \mathrm{~m}$ down to the sea-level. Geologically, the area is structured by metamorphic rocks of the alpine orogeny. Extensive outcrops of schists and karstified limestones and marbles delineate the plains and form the bedrock of the basin, whereas ophiolites of considerable spatial extent also exist, predominantly along the western and southeastern margins. The high degree of karstification of the carbonate rocks give rise to extensive aquifers of high potential that control the hydrogeological evolution of the region through numerous springs and lateral crossflows that recharge the alluvial aquifer systems of the plains.

The basin is sub-divided to the western and the eastern sub-basins that are separated by a hilly region structured of Neogene marls with intercalations of fine sandstones and to a minor extent limestones. Due to the active fault tectonics a great thickness of alluvia has been deposited that exceeds 450 to $500 \mathrm{~m}$ towards the central parts and progressively thin out at the margins. Groundwater resources exploitation is focused on the two main and the smaller peripheral alluvial basins, and also on the karstified systems. 
Surface water from the rich hydrologic network cover considerable part of irrigation demands especially at the western plain of the basin.

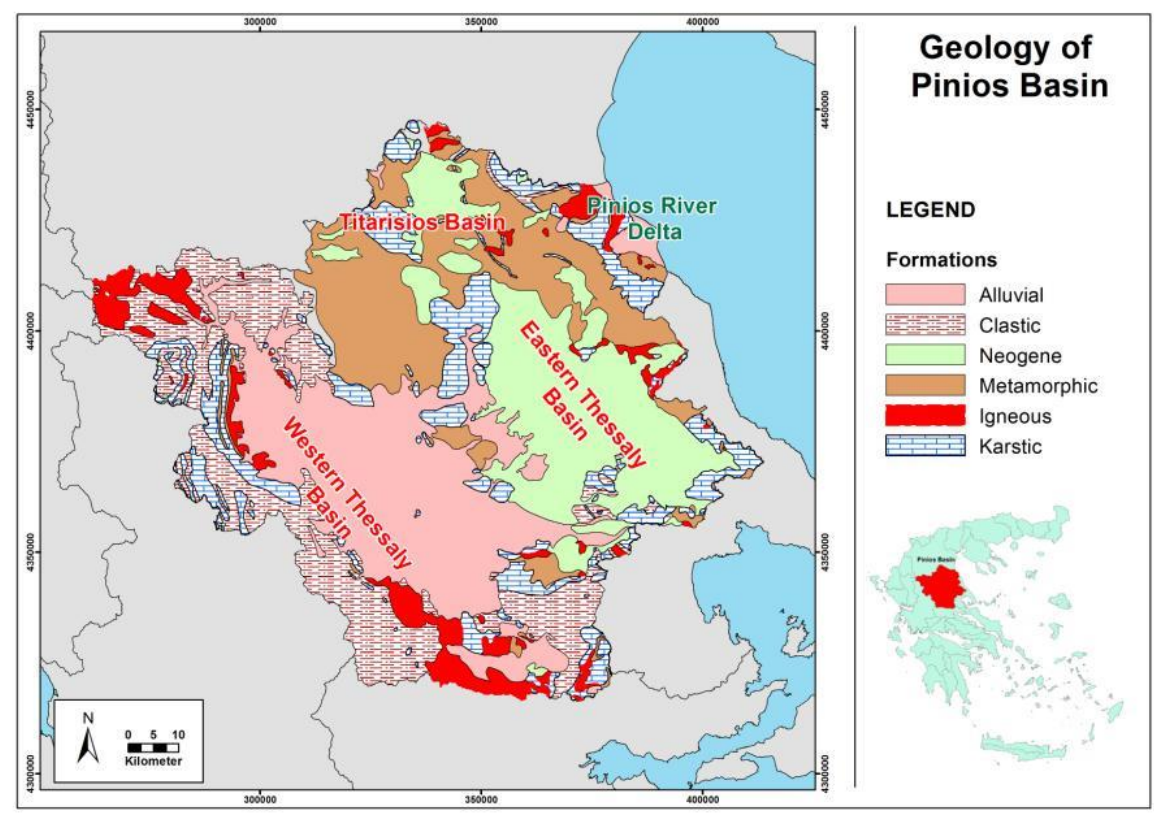

Figure 2. Geological regime of Pinios River Basin

A strong hydraulic interaction has been long documented between surface and groundwater resources of the basin in the form of either exfiltration or infiltration, depending on the area and the period of time considered (Kallergis and Christodoulou, 1972; Panagopoulos et al., 1995). Also, of paramount importance is the recharge of the alluvial systems by lateral crossflows especially from the karstified systems of the basin and also from the extensive talus cones and scree that exist in both plains, with typical examples the talus cone of river Sofaditis at the western plain and the river Titarisios at the eastern plain.

In the plain areas of Pinios Basin, intensive agricultural activities have frequently led to environmental pressures related to water resources. Due to adopted mismanagement practices signs of over exploitation have appeared as early as mid 1980's and a deficient water balance has been established in the last 3 decades. Groundwater overexploitation is believed to be the main cause for environmental deterioration along with the extensive use of fertilizers and pesticides (Panagopoulos et al., 2012). Groundwater levels are strongly controlled by the seasonal exploitation of the resources over the summer irrigation period, mainly exercised by numerous shallow but mainly deep wells that reach $400 \mathrm{~m}$. Over $85 \%$ of the totally available water resources (both surface and groundwaters) is used by agricultural activities (Hellenic Min. Environment, Energy and Climate Change, 2013). Extreme hydrologic events such as floods and droughts are quite common in the catchment.

\section{Methodology}

GROWA (Kunkel and Wendland, 2002) is a grid based empirical model, which has been developed to support practical water resources management issues of large river basins. It employs an empirical approach with a temporal resolution of one or more years. It calculates annual averages of the main water balance components, e.g. total runoff, percolation water rate, direct runoff and groundwater recharge, as a function of climate, soil, geology, topography and land use conditions. GROWA has been applied to regions ranging typically between mesoscale river basins (Herrmann et al., 2009) of approx. $1000 \mathrm{~km}^{2}$ up to entire States or river catchments of $100,000 \mathrm{~km} 2$ and more (Kunkel et al., 2006). In the regions where it has been applied the GROWA model results are used for practical water resources management related issues, e.g. the granting of permits to abstract groundwater on a regional level and for the status reviews 
of the groundwater bodies according to the EU Water Framework Directive (Tetzlaff et al., 2004; Herrmann et al., 2009; Wendland et al., 2010). The general methodological flow-chart of GROWA model application is presented in Figure 3.

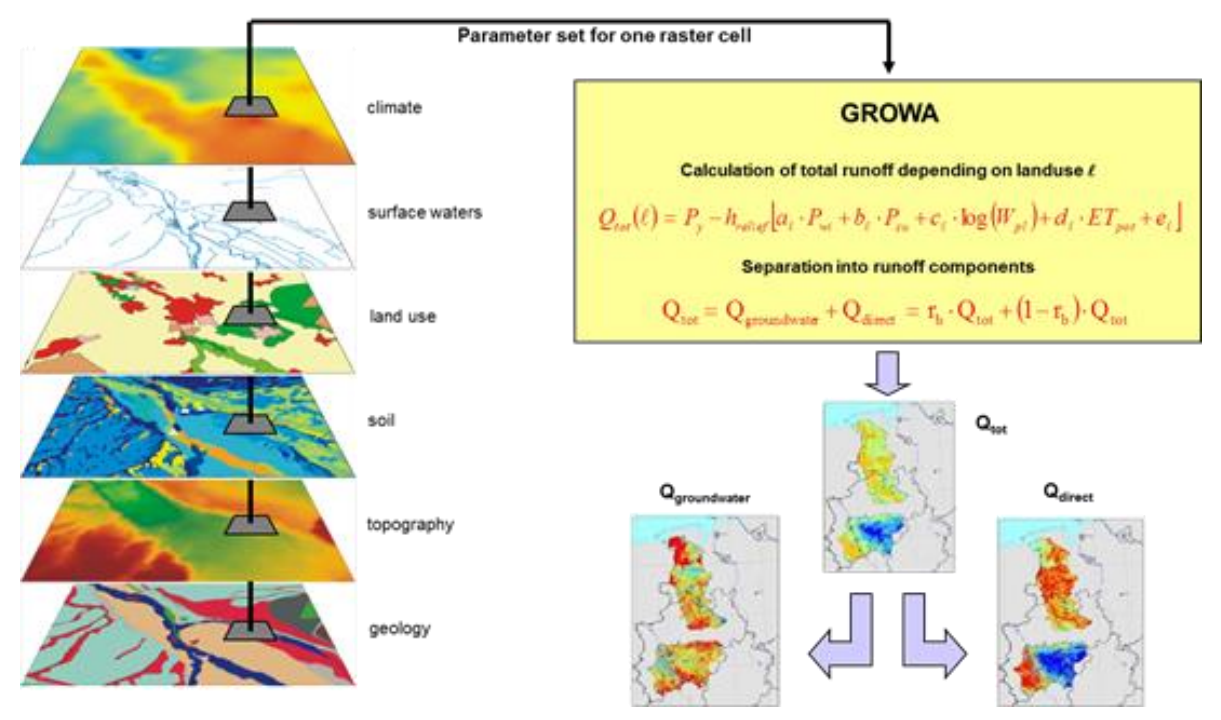

Figure 3. Methodological flow-chart of GROWA model

Water balance modeling is performed in three steps. In a first step the mean long-term evapotranspiration rates (Eta) are determined according to an approach from Renger \& Wessolek (1996), which has been extended for mountainous areas (Golf, 1981), urban areas (Wessolek and Facklam, 1997; Tetzlaff et al., 2004) and regions close to the groundwater table (ATV-DVWK, 2002). In a second step mean annual total runoff rates are calculated grid-wise as the difference between the mean annual precipitation rate and the mean annual actual evapotranspiration rates.

In the third step, total runoff is separated into direct runoff and groundwater runoff. Whereas direct runoff designates the sum of the fast runoff components (surface runoff, natural interflow and drainage runoff), groundwater runoff is equal to the runoff components, which reach the surface waters after passing through an aquifer. The separation is done on the basis of several geo-factors, which take into account the degree of sealing, artificial drainage, petrographic properties, depth of groundwater, perching water and slope. Reference values from literature (e.g. Wessolek and Facklam, 1997; Wendland et al., 2003; Tetzlaff et al., 2009) are used as starting points for the assignment of grid related BaseFlow Index (BFI)-values.

Input data required for the model analysis included the compilation of various spatially distributed thematic maps. Data was obtained by multiple sources (national, international, field works) and subsequently was homogenized and regionalized. Field works included soil sampling and analyses in specific areas where lack of accurate data emerged, or more detailed information was required. All the acquired data were processed with the aid of Geographical Information Systems (GIS) software.

Prior to GROWA model run in Pinios Basin, initial data preparation and regionalization was required. Spatially distributed grid-based $(100 \times 100 \mathrm{~m})$ digital maps (climatic, hydrological, pedological, topographic and hydrogeological) were produced, as a combination of the variable sources, frequently existing in different scales, hence regionalization and homogenization was inevitable and fundamental. Below are described shortly the main processes carried out, in order to create the required data sets. All climatic data originated from the Hellenic National Meteorological Service (HNMS) and the Hellenic Ministry for Rural Development and Food and accounted for the time frame 1980-2002. Used data set originated from 64 meteorological stations in total and managed to derive area-differentiated values for precipitation and potential evapotranspiration (14 stations used) through Thornthwaite method (Thornthwaite, 1948) with the aid of spatial interpolation after the essential topographic corrections. 


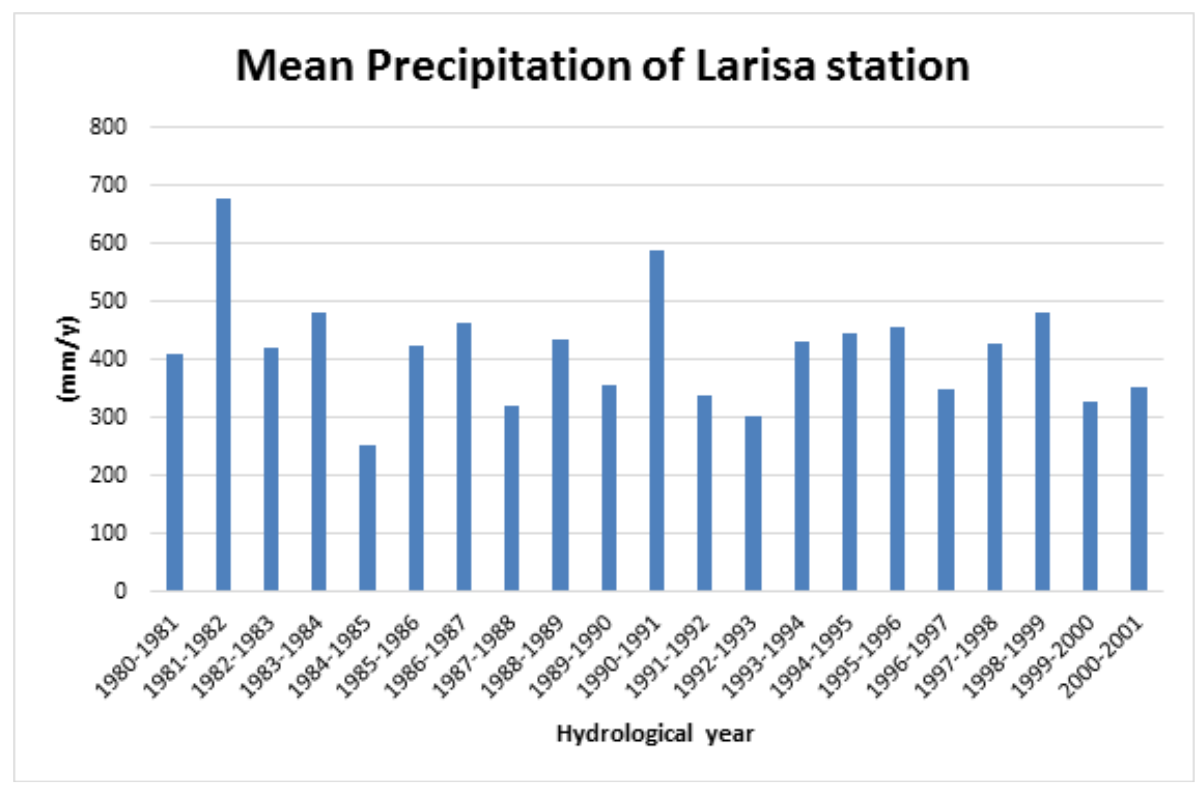

Figure 4. Mean precipitation values $(\mathrm{mm} / \mathrm{y})$ for Larisa station (considered as representative for Pinios Basin) for the period of 1980-2001. Calculations based on monthly values

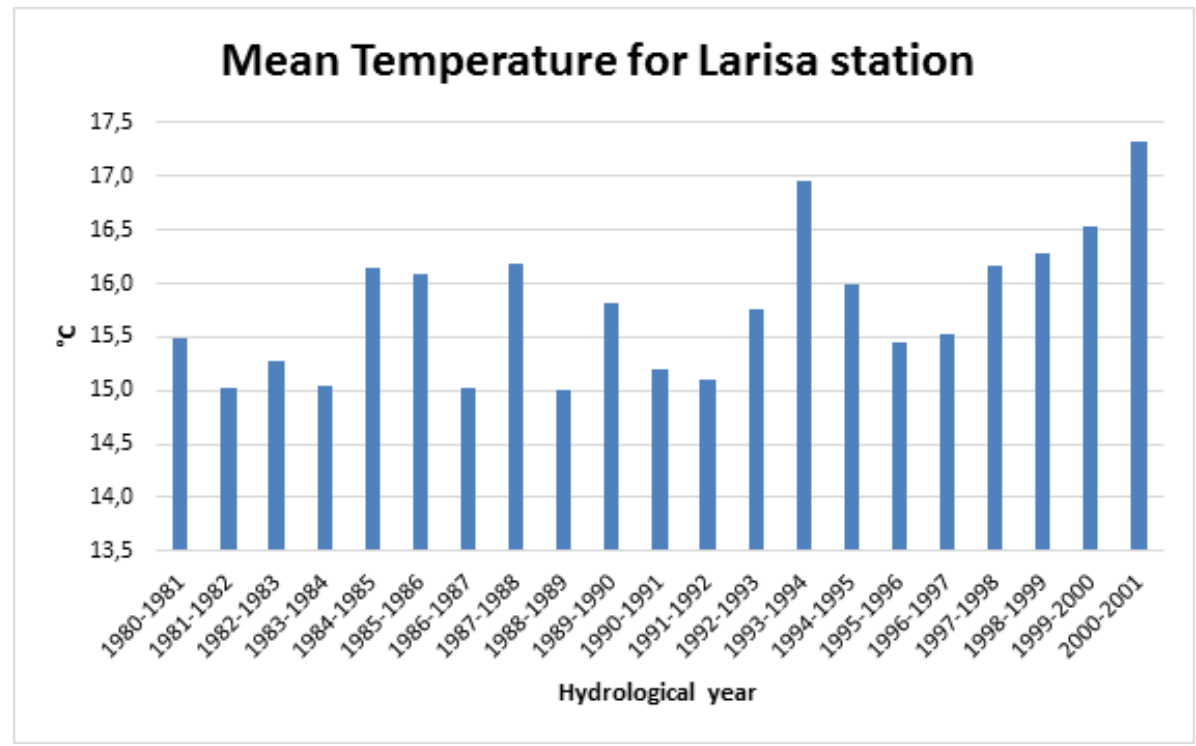

Figure 5. Mean temperature values $\left({ }^{\circ} \mathrm{C}\right)$ for Larisa station (considered as representative for Pinios Basin) for the period of 1980-2001. Calculations based on monthly values

The plant available soil water $(\mathrm{Wpl})$ was calculated on a grid base $(100 \mathrm{~m} \times 100 \mathrm{~m})$ as a combination of three interlinked parameters, namely effective field capacity $(\mathrm{eFC})$, effective rooting depth and capillary rise. Spatially differentiated values of effective field capacity derived through the soil parameters of texture, soil depth and organic content which were acquired from open source digital maps provided by Harmonized World Soil Data base (HWSD) and field works (sampling and analyses of soil samples). Based on CORINE land cover classification (EEA, 1985) the effective rooting depth of the dominant cultivations was spatially defined and attributed to the designated grid base. Finally, areas with capillary rise were set as buffer zones near the riverbeds of the main drainage network, as well as in the vicinity of surface reservoirs and wetlands. This assumption was considered valid as groundwater levels and/or top of aquifers of essentially all groundwater bodies within the basin lay much lower than the critical depth of $1-2 m$ below surface, so it was assumed that capillary rise might have effect only in areas were surface hydrology was dominant. 
A Digital Elevation Model - DEM (discrepancy $25 \mathrm{~m}$ ) was used to replicate the topographic relief of the basin that has a strong influence on the determination of the water balance through the slope gradient and the aspect that affects actual evapotranspiration levels. Finally, groundwater recharge level was determined by separating the calculated total runoff into components of direct runoff and base flow. Raw data included the compilation of a homogenized digital geological map, based on the geological mapping in 1:50.000 scale elaborated by the Hellenic Institute of Geology and Mineral Exploration (IGME). Subsequently, the consolidated formations were categorized according to their hydro-lithological properties and their hydraulic conductivity values, and they were attributed a BFI value which was used for the final calculations.

\section{Model results}

\subsection{Total runoff and basic components}

Area differentiated water balance modeling was performed according to the described procedure with a series of long-term average climatic and hydrological data for a reference period of 23 years (1980-2002). The estimated individual parameters included total runoff, and its major components, namely direct runoff and groundwater recharge. Results are illustrated in annual mm values (Figures 6, 7 and 8).

As can be seen from Figure 8, average annual total runoff levels vary between few millimeters and 1844 $\mathrm{mm} / \mathrm{y}$ with a mean value of $221 \mathrm{~mm} / \mathrm{y}$. The lowest values are exhibited the eastern part of the basin (eastern Thessaly basin) and are less than $50 \mathrm{~mm} / \mathrm{y}$. Overall, a decrease trend is captured from the mountainous to the plains areas and also from the west to the east, which is in good agreement with the analysed distribution of precipitation and evapotranspiration. In general, low levels of total runoff (less than $200 \mathrm{~mm} / \mathrm{y}$ ) within Pinios Basin are indicated at nearly $70 \%$ of the total areal extent. On the contrary, in the mountainous areas at the west and northeast, total runoff reaches its highest values as a result of low temperatures (hence low evapotranspiration) and high precipitation depths. Based on Figure 7, most of the covered area appears to have low values of direct runoff, in accordance with the general distribution of total runoff that is low as previously discussed. More specifically, values range from zero in some parts of the plain areas to $1621 \mathrm{~mm} / \mathrm{y}$ in the mountainous region, with a mean value of $138 \mathrm{~mm} / \mathrm{y}$, probably as a result of negligible total runoff and practically zero slope values (especially in plain areas). The elevated values which account for some parts of the mountainous areas (or in few cases semimountainous) should be attributed mainly to one or more of the following factors: high precipitation values, steep topography, and practically impermeable geological substrate.

Groundwater recharge (Figure 8) varies between 0 and $1588 \mathrm{~mm} / \mathrm{y}$ with a mean value of $92 \mathrm{~mm} / \mathrm{y}$, but in the majority of the studied area is very limited (less than $50 \mathrm{~mm} / \mathrm{y}$ ). This is the result of the dominant geological conditions, which are dictated by formations of low permeability at the soil surface of the plains that considerably limit direct infiltration to groundwater bodies, and of course due to the indicated general total runoff trend. Major groundwater runoff components appear to be distributed along the karstic domains and the margins of the basin where favourable conditions for groundwater recharge occur. These are the regions were groundwater bodies are predominantly recharged through lateral crossflows from surrounding highly permeable formations (Hellenic Min. Environment, Energy and Climate Change, 2013; Alexandridis et al., 2014), and also through direct infiltration along zones of highly permeable deposits, such as the extensive talus cones and scree described in paragraph 2 of this paper. 


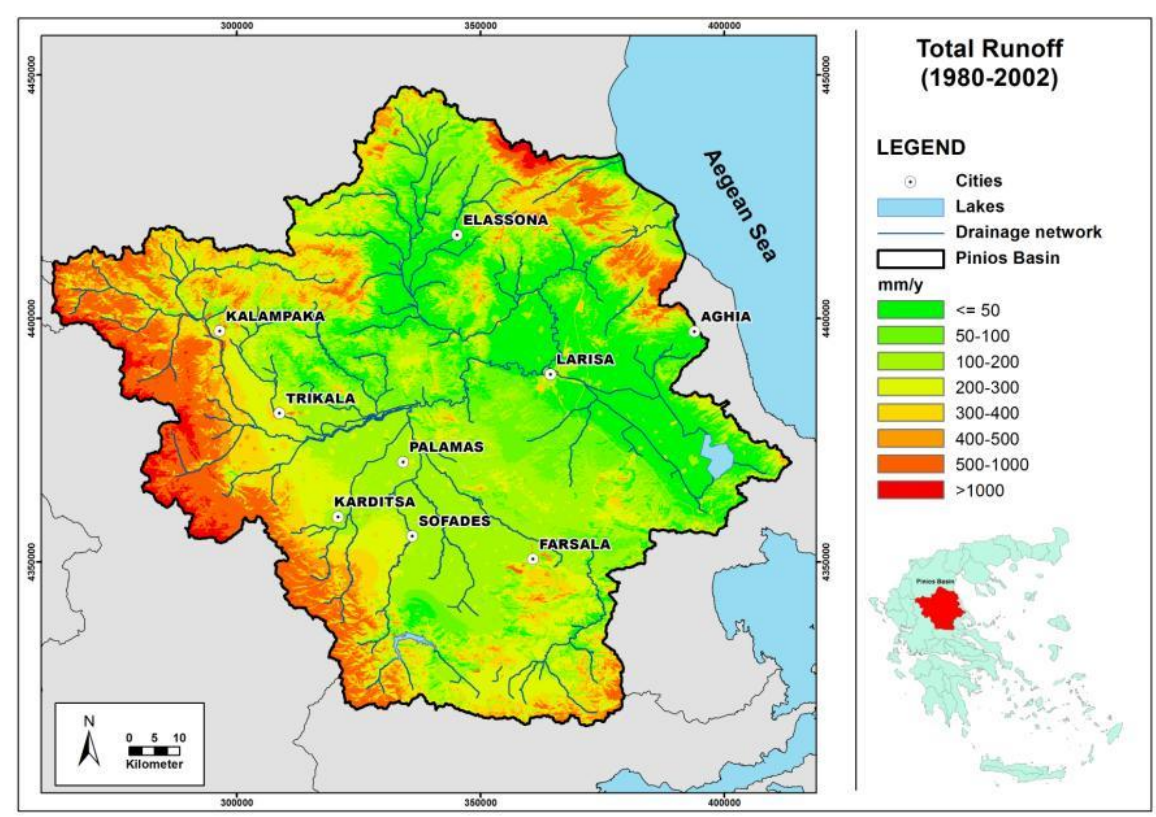

Figure 6. Average annual total runoff in Pinios River Basin for the period 1980-2002

\subsection{Dominant runoff components}

Apart from the overall estimation of total runoff and its components, it is critical to have a spatially distributed comparison among them, especially when planning strategic water management schemes, which require detailed spatially differentiated quantitative data. As a result of that process the map of Figure 6 may be derived, which depicts the spatial differentiation of the dominant runoff component between groundwater recharge and direct runoff.

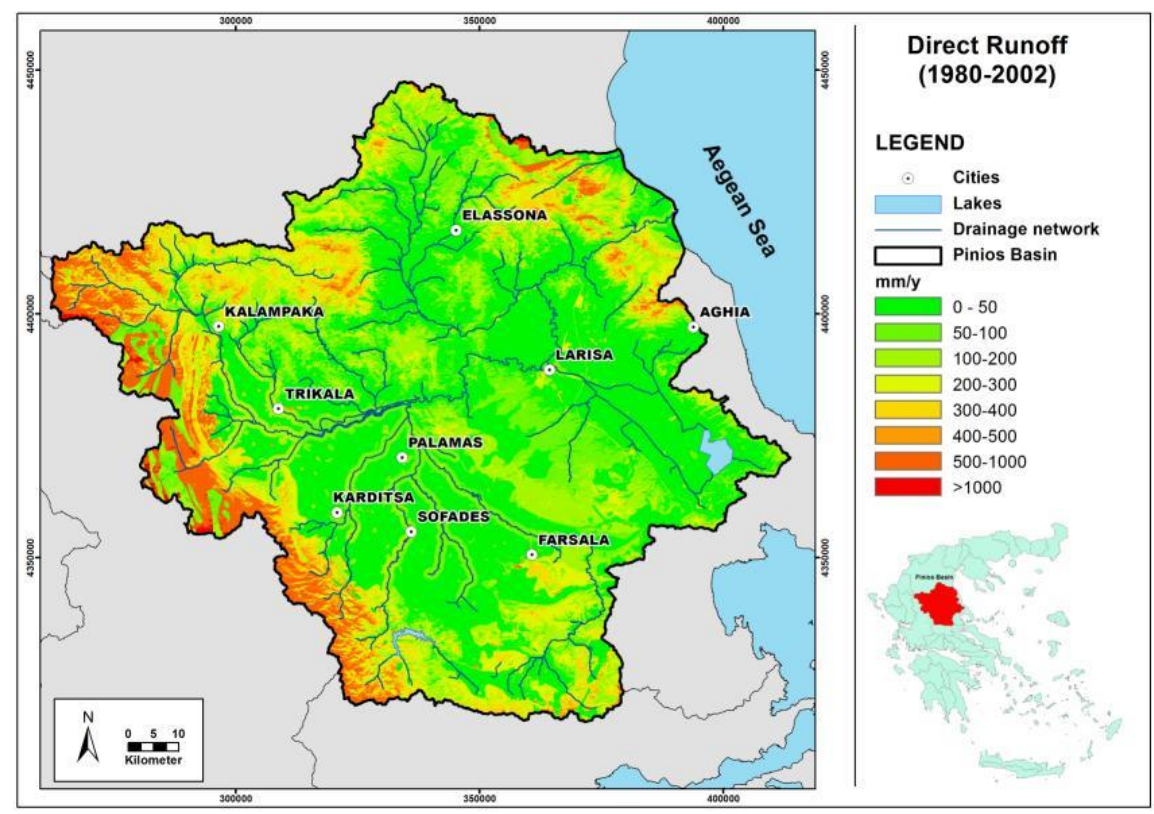

Figure 7. Average annual direct runoff in Pinios River Basin for the period 1980-2002 


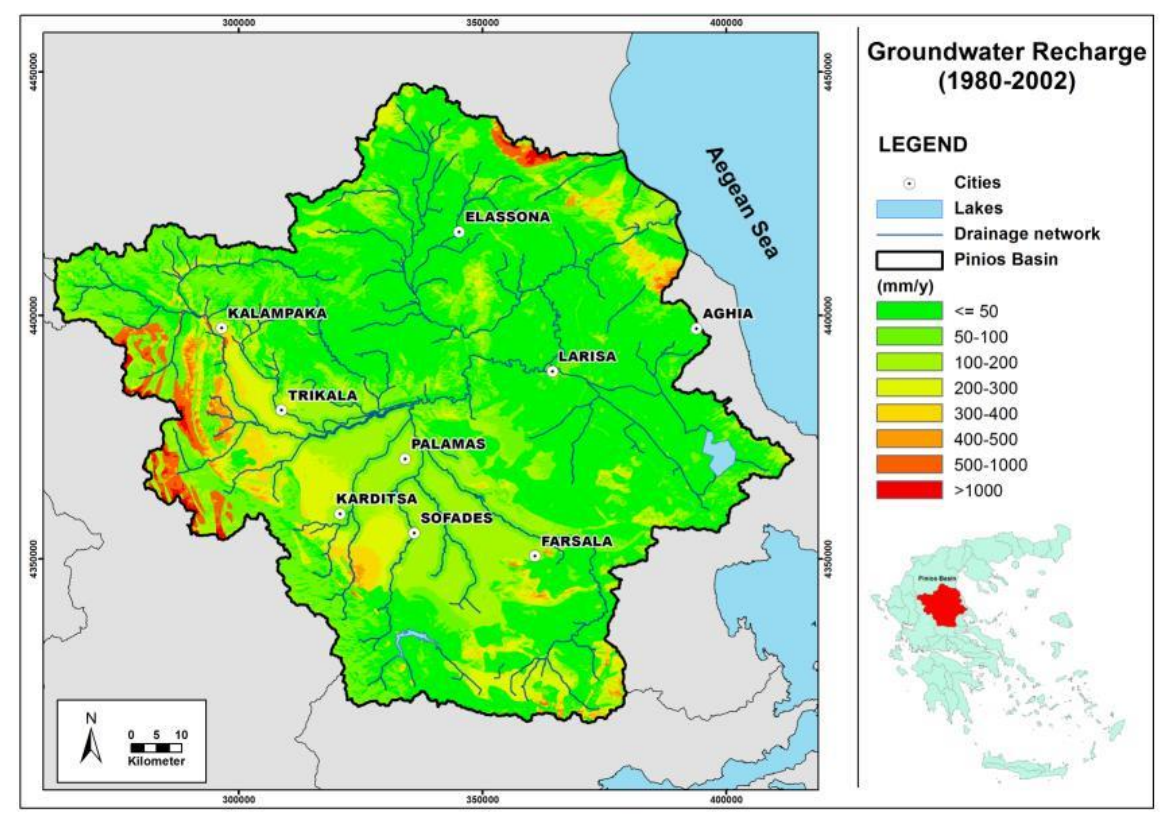

Figure 8. Average annual groundwater recharge in Pinios River Basin for the period 1980-2002

As seen in Figure 9, groundwater recharge is the dominant component in the western Thessaly plain (Sofades, Palamas, Karditsa, Trikala) as well as at the part of eastern Thessaly plain, which lays mainly western-northwestern of Larisa city. The discussed areas are characterised by very low topographic relief, thus essentially flat surface, which also favours recharge and reduces effectively the surface runoff component. Especially for the eastern sub-basin, soil texture is progressively getting fine-grained towards southeast according to sample analyses and the geological structure of the region, a fact that is explicitly reflected at the transition of groundwater recharge values (ratio vs. total runoff is declining from over $80 \%$ to $40-60 \%$ ). Based on regional geological and hydrolithological conditions (Panagopoulos, 1996), the dominance of groundwater recharge is expected in the western part of the eastern sub-basin.

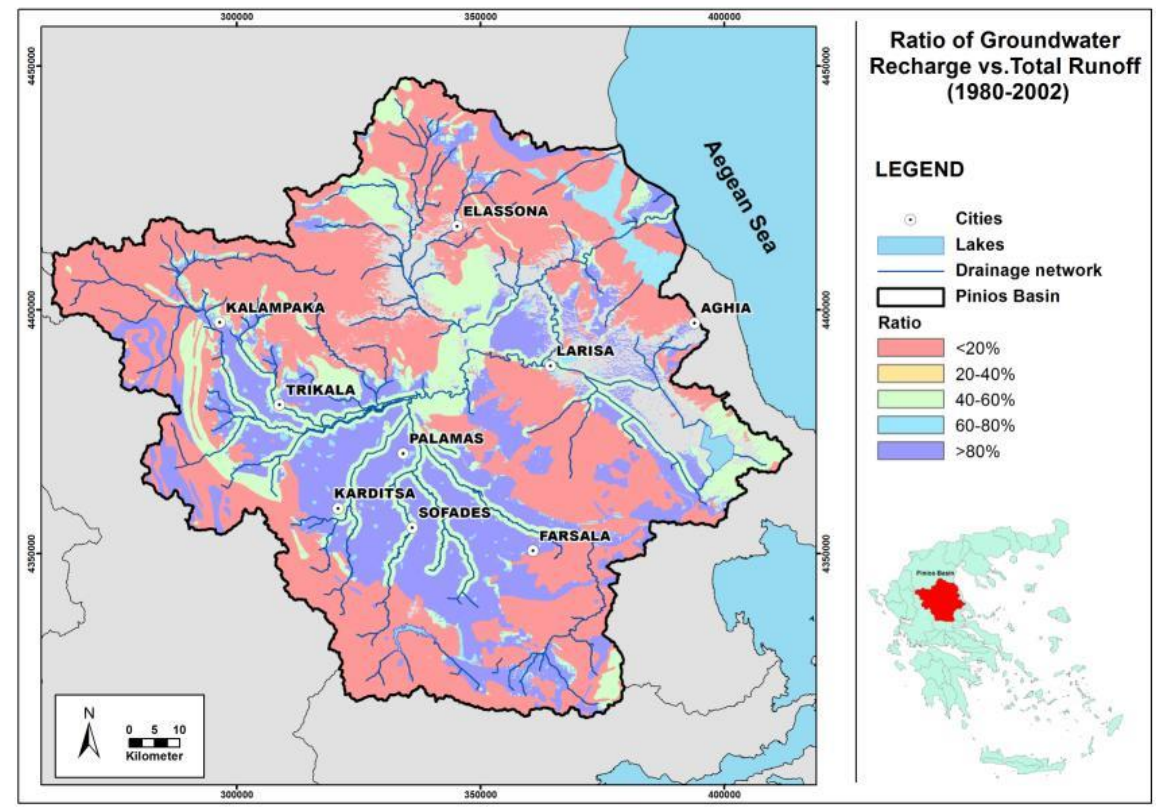

Figure 9. Ratio of groundwater recharge vs. total runoff in Pinios River Basin for the period 1980-2002 
Steep topography is critical for the dominant runoff component of the area which lies northwestern of Larisa city and appears as a narrow stripe with a SW-NE direction. This is the area where the extensive karstic system of Tirnavos-Damasi-Koutsohero crops out; it plays a controlling role over the regional hydrogeologic evolution and is characterised by a high degree of karstification (Panagopoulos et al., 1995). Aforementioned fact along with the high slope gradients seem to control runoff components and result to a ratio between groundwater recharge and direct runoff nearly equal to one (groundwater recharge vs. total runoff ratio is $40-60 \%$, i.e. in fair agreement to the degree of karstification, as reported by Soulios (1985). At the rest of the study area direct runoff is dominant as a result of local geology, soil factors, vegetation and topography.

\subsection{Model validation}

The reliability of the calculated area-differentiated runoff levels was validated against long-term discharge data from 12 gauging stations (Figure 10) that exhibit a fair spatial distribution over the study area. The selection of gauging stations was based primarily on their representativeness as well as on the availability of long-term data series, at least equal to the time-series used for the model run (1980-2002). Representativeness was assured by including gauging stations with the greatest possible variability with respect to the size and geomorphology of catchment areas as well as land use and climate. The associated gauge-related sub-catchment areas were classified primarily using digital data obtained by Hellenic Open Government Initiatives, and when required, more detailed spatial classification was achieved through G.I.S. hydrological modeling and expert judgment based on local conditions (geology, hydrology, hydrogeology). Totally 17 sub-catchments were identified that form the main Basin of River Pinios (Figure 10). Practically, each of the selected monitoring stations gauges the discharge of a sub-catchment, hence validation is carried out by comparing the real (measured) discharge value with the one calculated by GROWA model (Table 1).

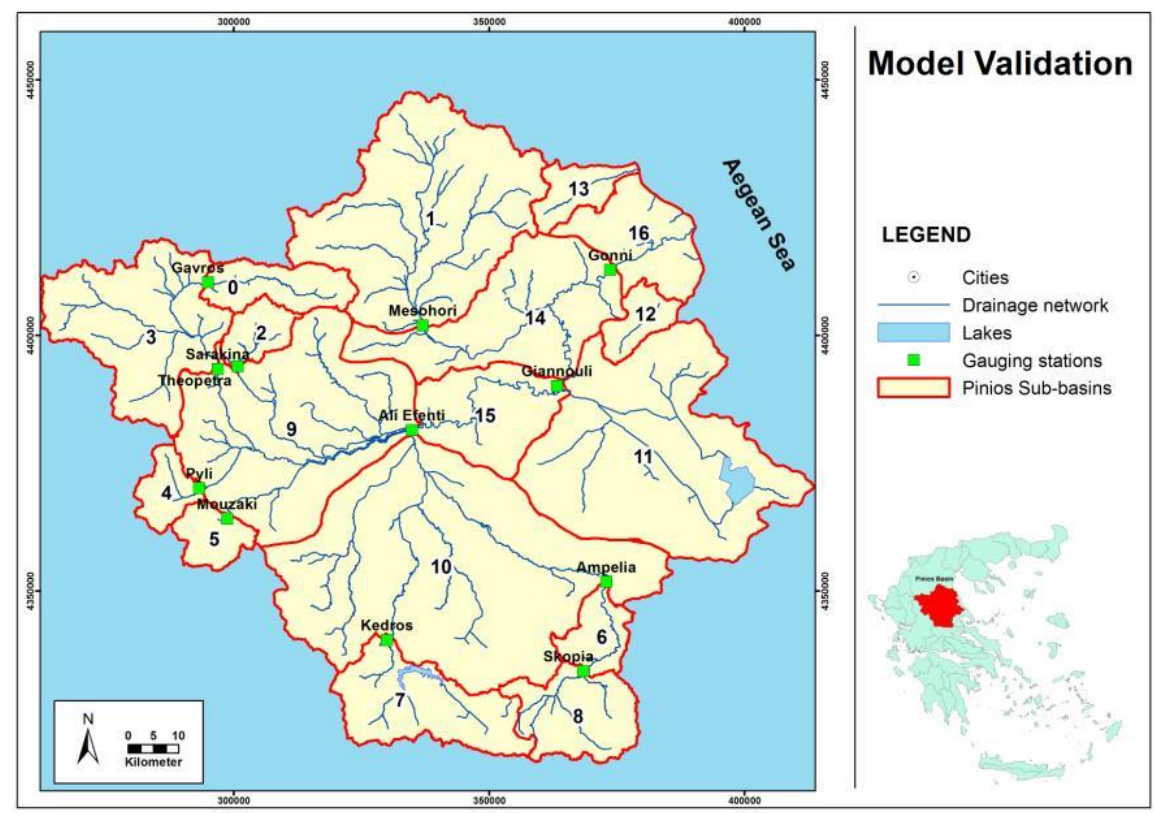

Figure 10. Gauging stations used for validation and sub-catchment areas classification of River Pinios Basin

The preparation of data for validation included the integration of direct runoff values for each of the gauge-related sub-catchments in order to obtain a mean annual value. Taken into account that calculated values refer to mean annual runoff, the measured ones should be processed accordingly in order to be comparable. To achieve that, measured monthly values were integrated in order to acquire a mean value for the entire time period of the data set. As GROWA model takes into account only the point (grid-based) values of runoff within an individual basin without considering the cumulative effect of hydrological 
processes and possible recharge from adjacent sub-basins, subsequent arithmetic calculations were essential in order to subtract the discharge values of hydrologically connected (upstream) sub-catchments (e.g. no 6-8, when calculating discharge at sub-basin 10), thus comparing with the correct runoff values and not possible overestimates that would have occurred otherwise.

Table 1. Validation of calculated total runoff with the use of gauged (measured) values

\begin{tabular}{ccccc}
\hline Sub-catchment & Gauging station & River & $\mathbf{Q}_{\mathbf{d}}$ Gauged $\left(\mathbf{m}^{\mathbf{3}} \mathbf{s}^{-1}\right)$ & $\mathbf{Q}_{\mathbf{d}}$ Modelled $\left(\mathbf{m}^{\mathbf{3}} \mathbf{s}^{-1}\right)$ \\
\hline 9 & Ali Efenti & Pinios & 36.21 & 35.53 \\
\hline 15 & Giannouli-Larissa & Pinios & 65.00 & 38.59 \\
\hline 6 & Ampelia & Enipeas & 3.00 & 2.52 \\
\hline 0 & Kedros & Sofaditis & 6.31 & 4.17 \\
\hline 5 & Gavros & Ion & 1.21 & 2.02 \\
\hline 1 & Mouzaki & Pamisos & 3.33 & 2.37 \\
\hline 4 & Mesohori & Titarisios & 5.28 & 5.03 \\
\hline 3 & Pyli & Portaikos & 4.80 & 2.10 \\
\hline 8 & Sarakina & Pinios & 11.06 & 11.73 \\
\hline 2 & Skopia & Enipeas & 1.64 & 1.76 \\
\hline 14 & Theopetra & Litheos & 1.91 & 0.58 \\
\hline
\end{tabular}

On that basis, validation was successfully achieved by comparing the measured against the modeled values of total runoff in 12 sub-catchment areas. The measure of validity was based on the coefficient of determination $\left(R^{2}\right)$ between these two values which is nearly 0.92 (Figure 8 ), and according to the statistical interpretation (Steel and Torie, 1960) corresponds rather well to the likelihood that future outcomes will be successfully predicted by the model.

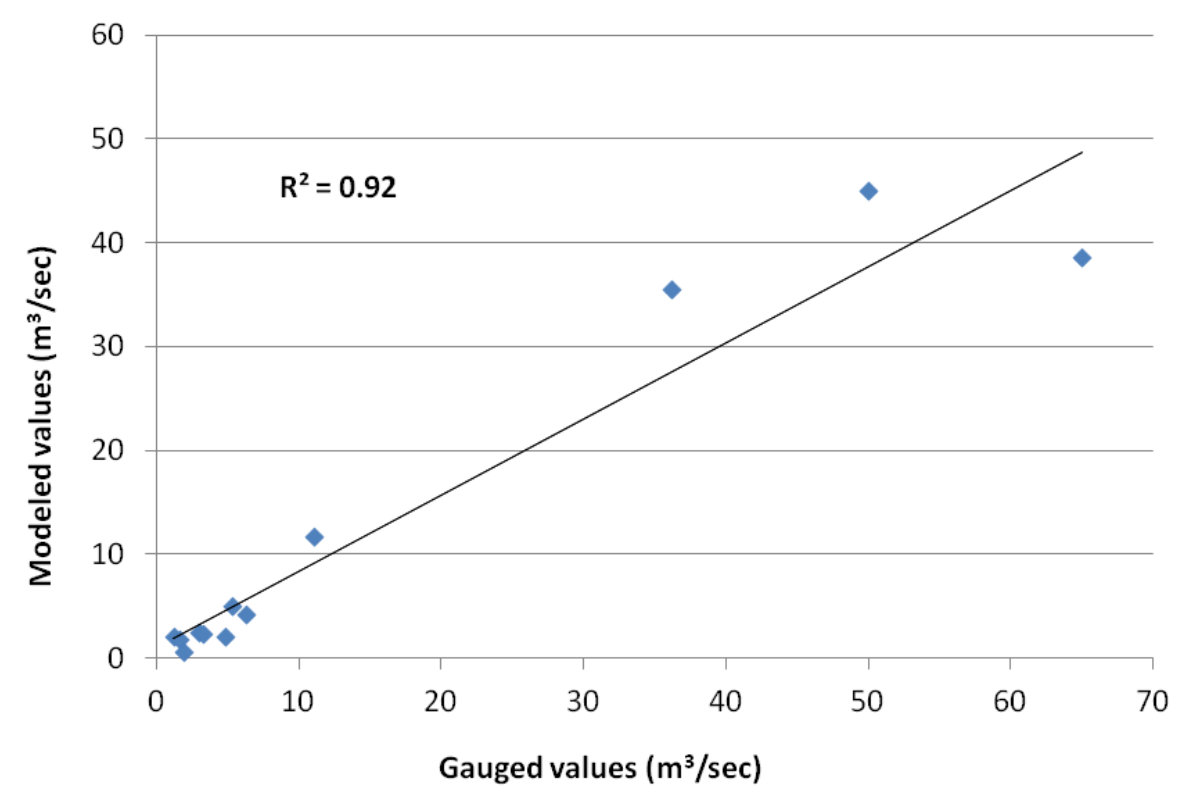

Figure 11. Correlation and coefficient of determination between measured and calculated total runoff values for all gauging stations

In general there is a good agreement at low to intermediate discharge ranges that correspond to the peripheral mountainous small to medium size sub-catchments. A considerable discrepancy is noted on high discharge rates that correspond to the sub-catchments relating to the main plains of the catchment. 
In detail, Table 1 and Figure 11 may document that the variation between measured and modeled values is low in the sub-catchments that discharge mountainous areas (e.g. no's $0,1,3,4,5,6,8$ ), a fact which denotes the successful application of GROWA model to the study area. Even though in some cases the variation seems to be significant in terms of absolute percentages (e.g. No 0, 2, 3 etc) the values of discharge are so low that fall within the discrepancy error of the model and the integration of measured values.

On the contrary, model results seem to vary significantly from the measured values for the sub-catchment areas 9 and 15 (gauging stations Ali Efenti and Giannouli-Larissa respectively), which are located in the core parts of the plain and refer to water discharged from the upstream mountainous sub-catchments plus water collected along the river courses at the plains. This is attributed to the fact that GROWA determines runoff generation including infiltration into the aquifers, but does not consider any secondary hydraulic interactions: losses from or gains to the aquifer systems.

In the case study area the losses are related to the hydraulic interaction between surface water (mainly River Pinios) and groundwater and the lateral crossflows that are a controlling hydraulic evolution mechanism. Both mechanisms are extremely important in terms of water budgeting in between gauging stations nos 9 and 15 (Ali Efenti and Giannouli-Larissa, respectively) and relate to the hydraulic functions of the extensive karstic system of Tirnavos-Damasi-Koutsohero. The most important losses however originate from water abstractions for irrigation purposes. Numerous wells that are estimated to exceed 30000 , abstract groundwater to cover part of the regional irrigation demands. Several collective irrigation networks operate that cover their water needs from direct abstractions from the River Pinios and its tributaries. Based on the latest estimates, abstractions from surface water bodies sum up to about 5400 $\mathrm{hm}^{3} / \mathrm{y}$ and from groundwater about $800 \mathrm{hm}^{3} / \mathrm{y}$, (Min. Environment, Energy and Climate Change, 2013).

The measured value at Gonni gauging station (see table 1, no. 14), which is located at the downstream part of the basin just before discharging into the deltaic sub-basin of River Pinios, reflects the overall water balance of the basin. The comparison of the runoff values shows minor deviations only. This is to the outbalancing of water losses from lateral crossflows and/or direct abstractions along the river courses at the sub-catchment scale on one hand and the gains to the system by recharge mainly from the karstic domains of the basin on the other hand, especially the large system of Tirnavos-Damasi-Koutsohero, located at the NW margin of the eastern Thessaly plain.

Validation is focused on the comparison of the total runoff at the selected sub-basins as already discussed. Mean monthly low flow measurements at the gauging stations would normally be compared against the groundwater runoff element of the model, as an additional validation procedure. However, for the particular study area such an exercise would have been of low credibility, or even misleading for the following reasons. Available discharge measurements for the recession period (summer-time) are sparse, hence not representative of the overall evolution of the system. Moreover, summer time discharge in the hydrologic network of the study basin is rather limited due to the prevailing climatic conditions and the depth to groundwater levels. Exactly due to the prevailing hydrological and climatic conditions, during the summer irrigation period systematic interventions on the river courses are practiced, which influence the natural low flow of the watercourses. As direct abstractions from the rivers cover part of the irrigation demands, the existing discharge measurements do not reflect the natural low flow conditions. Consequently, the use of such values for model validation of groundwater recharge would be misleading.

\section{Conclusions}

Despite the fact that originally GROWA was developed for totally different climatic, pedological, hydrological and hydrogeological conditions it was successfully applied to a typical Mediterranean Basin.

In the mountainous and semi-mountainous areas where runoff is the sole controlling factor, GROWA results are simulating rather accurately the natural system. Regarding plain areas there was a significant variance between the observed and the modeled values in one of the considered gauging stations. However, this deviation could be explained by considering specific hydrodynamic evolution mechanisms 
and anthropogenic impacts that cannot be directly accounted for in the model. Hydrodynamic evolution mechanisms relate to a) extensive hydraulic interaction zones within the riverbed of the main river system which leads to either water losses or gains (depending on the specific area referring to and also the temporal period addressed), b) discharge of the aquifer systems in the form of water emerging from springs, c) discharge or recharge of the aquifer systems through lateral crossflows. Anthropogenic impact is profound and related with water abstraction mainly for irrigation purposes. This fact should be stressed if the overall demand of the cultivations is considered and the water scarcity that is often experienced during the last decades in Thessaly is taken into account.

As a whole, GROWA responds well to water balance simulation and this may be additionally verified if the "problematic" gauging station (no 15, Giannouli-Larisa) is filtered form the validation process. In such a case, the outcome is very encouraging as the coefficient of determination $\left(R^{2}\right)$, which is 0.99 , almost reaches the perfect match between measured and modeled values (Figure 12).

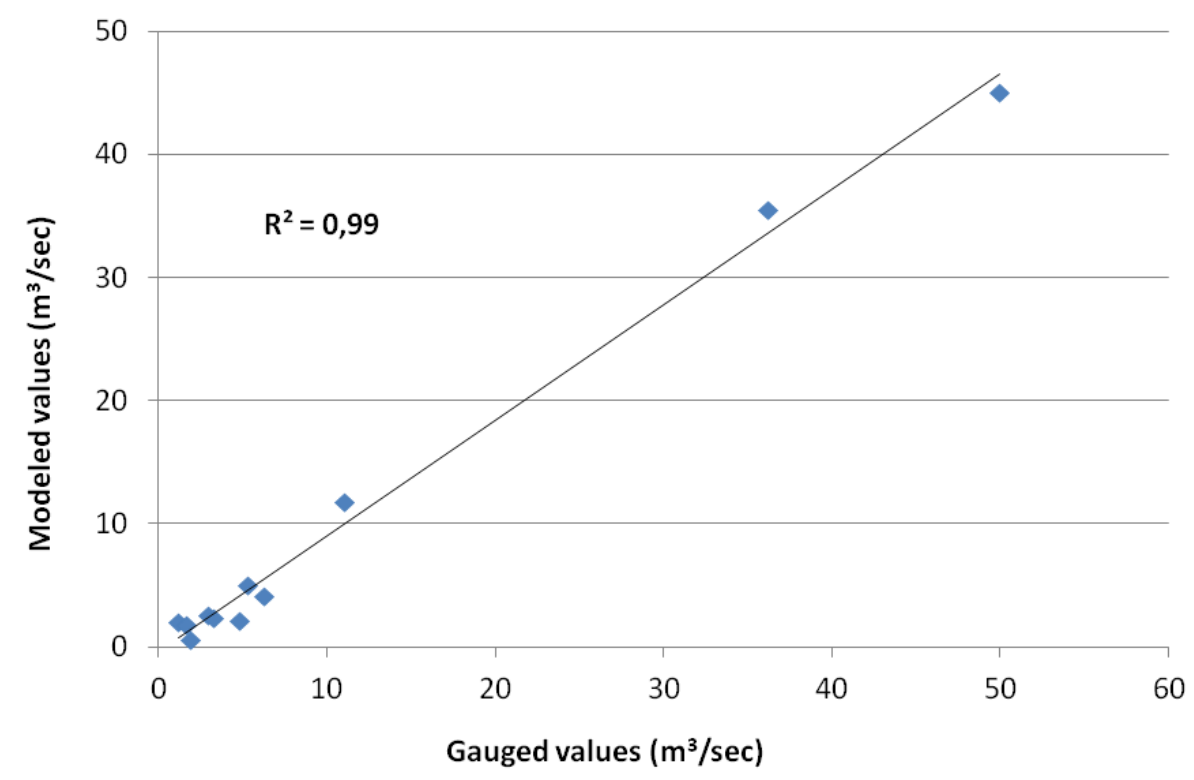

Figure 12. Correlation and coefficient of determination between measured and calculated total runoff values for all gauging stations except Giannouli-Larisa

As an overall conclusion, model reliability is very satisfying. Greater deviations between measured and observed runoff values could be explained by secondary processes. The differences between measured and modeled values for the plain areas can be sufficiently explained accounting for the water volumes abstracted from the system or added to the system due to aforementioned processes.

Observed discrepancies may therefore be attributed to the following specific factors: 1) Poor monitoring data quality due to the conditions under which river gauging is carried out. Moreover, the fact itself that only a single measurement is available per month signifies the inherent uncertainty of the value. 2) Water resources management practices are not incorporated in the calculations thus leaving space for discrepancies in the water balance simulations. This is quite important especially in a region, which is characterized by extreme exploitation of available resources, at least over the experienced periods of droughts. 3) The hydrodynamic mechanisms that control groundwater evolution in the region deviate from the conceptual approach upon which GROWA operates. Consideration of such processes would benefit the calculated water balance.

This implies that a recalibration of the GROWA model with the aim to reduce the gap between the observed runoff values and the modeled runoff values would be a step into the wrong direction in the case of the Pinios river basin. The modified runoff generation values for the individual grids, which would have been the result of the recalibration process, would have obviously "improved" the model 
performance by increasing the $\mathrm{R}^{2}$. In reality however, runoff generation for the individual grids would have been represented worse. From this finding we conclude that prior to model recalibration efforts special attention should be given to the inclusion of secondary processes (water gains and losses), as these were discussed, into the model runs. The River Pinios basin case study has shown that hydrological model results about e.g. total runoff and groundwater recharge should consequently be linked with the overall water use and secondary inputs before they are used for strategic water resources management. Evidently, a denser and more frequent river discharge monitoring network would enhance the performance of the model, especially given the fact that the particular basin exhibits a highly contrasting evolution of its water resources in response to seasonal climatic conditions and prolonged drought events. Nevertheless, the performed modelling exercise provided results that are valid and useful in the context of regional water resources management.

\section{References}

Alexandridis T.K., Panagopoulos A., Galanis G., Alexiou I., Cherif Y., Chemin Y., Stavrinos E., Bilas G. and Zalidis G.C. (2014), Combining remotely sensed surface energy fluxes and GIS analysis of groundwater parameters for irrigation system assessment, Journal of Irrigation Science, 32, 127-140.

ATV - DVWK (2002), Evapotranspiration related to land use, soil cover and Soil. Merkblatt ATV-DVWK M 504, 139 p.; Hennef (in German).

Crawford N.H. and Linsley R.K. (1966), Digital simulation in Hydrology - Stanford Watershed Model IV. Technical Report No. 39, Department of Civil Engineering. Stanford University; Stanford, California, USA.

European Environment Agency (1985), http://www.eea.europa.eu/publications/CORO-landcover. Accessed 18 December 2012

EU-WFD: Directive 2000/60/EC of the European Parliament and the Council of the European Union of 23 October 2000 establishing a framework for Community action in the field of water policy, L 327, 73 S. Off. J. Eur. Communities (2000)

Golf W. (1981), Determination of water resources in midland areas.- Wasserwirtschaft-Wassertechnik 31 : 93-95 (in German).

Hellenic Min. Environment, Energy and Climate Change (2013), Compilation of management plans for the river basins of the Water Districts of Thessaly, Epirus and Ditiki Sterea Hellas, in accordance to the specifications of Directive 2000/60/EC, in implementation of Act 3199/2003 and P.D. 51/2007 - Water Resources Management Plan, Water District of Thessaly. Athens, $246 \mathrm{p}$.

Herrmann F., Jahnke C., Jenn F., Kunkel R., Voigt H-J., Voigt J. and Wendland F. (2009), Groundwater recharge rates for regional groundwater modelling: a case study using GROWA in the Lower Rhine lignite mining area, Germany, Hydrogeology Journal, 17(8), 2049 - 2060.

Jankiewics P., Neumann J., Duijnisveld W.H.M., Wessolek G., Wycisk P. and Hennings V. (2005), Runoff level, percolation water rates and groundwater recharge- three issues in the Hydrologic Atlas of Germany. Hydrologie und Wasserbewirtschaftung 49 (1), S. 2 -13 (in German).

Kallergis G. and Christodoulou T. (1972), Effective infiltration-precipitation relationship at the alluvial deposits of Kalambaka area (western Thessaly), Bul. Geological Society of Greece, 9(1), 119-128.

Kunkel R. and Wendland F. (2002), The GROWA98 model for water balance analysis in large river basins - the river Elbe case study, Journal of Hydrology, 259, 152-162.

Kunkel R., Bogena H., Tetzlaff B. and Wendland F. (2006), Digital groundwater recharge map of the Federal States of Lower Saxony, North-Rhine Westphalia, Hamburg and Bremen: determination and applications.- Hydrologie and Wasserbewirtschaftung, 50, 212-219 (in German).

Panagopoulos A. (1996), A methodology for groundwater resources management of a typical alluvial aquifer system in Greece. Ph.D. Diss, The University of Birmingham, $251 \mathrm{pp}$.

Panagopoulos A., Kassapi K.A., Arampatzis G., Perleros B., Drakopoulou S., Tziritis E., Chrysafi A.A. and Vrouhakis I. (2012), Assessment of chemical and quantitative status of groundwater systems in Pinios hydrological basinGreece. Proc. Int. Conf. Protection and restoration of the environment XI, Thessaloniki, pp. 511-517. 
Panagopoulos A., Lloyd J. and Fitzsimons V. (1995): Groundwater evolution of the Tirnavos alluvial basin central Greece, as indicated by hydrochemistry. Proc. $3^{\text {rd }}$ Panhellenic Conference of Hydrogeology, Heraklion, pp. 332-344.

Renger M. and Wessolek G. (1996), Determionation of groundwater recharge for individual years.- DVWKMerkblätter zur Wasserwirtschaft 238, 47 p.; Bonn (in German).

Soulios G. (1985), Contribution to the hydrogeological study of the karst aquifer systems of the Greek domain. Aristotle university of Thessaloniki, Thessaloniki.

Steel R. and Torrie J. (1960), Principles and Procedures of Statistics. New York: McGraw-Hill, 1960, pp. 187, 287.

Tetzlaff B., Kuh P., Vereecken H. and Wendland F. (2009), Aerial photograph-based de-lineation of artificially drained areas and their relevance for water balance and nutrient mod-eling in large river basins, Physics and Chemistry of the Earth, 34, $552-564$.

Tetzlaff B., Kunkel R., Taugs R., Dörhöfer G., Wendland F. (2004), Basics fort he determination oft he sustainable management of groundwater resources in the Metropol area Hamburg. - Schriften des Forschungszentrums Jülich, Reihe Umwelt/ Environment, Band 46, Forschungszentrum Jülich GmbH, Jülich, Germany, $87 \mathrm{~S}$. (in German).

Thornthwaite C.W. (1948), An approach toward a rational classification of climate, Geographical Review, 38(1), 55-94.

Wendland F., Behrendt H., Hirt U., Kreins P., Kuhn U., Kuhr P., Kunkel R. and Tetzlaff B. (2010), Analyses of agrarian and environmental measures to reduce the nitrogen loads of groundwater and surface water in the river basin district Weser.- Hydrologie und Wasserbewirtschaftung, 54. Jahrgang, Heft 4, August 2010, 231 - 244 (in German).

Wendland F., Kunkel R., Tetzlaff B. and Dorhofer G. (2003), GIS-based determination of the mean long-term groundwater recharge in Lower Saxony, Environmental Geology, 45, 273-278.

Wessolek G. \& Facklam M. (1997) site conditions and water balance of sealed areas.- Z. Pflanzenernähr. Bodenk., Vol. 160, pp. 41 -46 (in German). 